\title{
Assessing Thai Nursing College Students' Speaking Ability through the Perspectives of Their Indonesian Counterparts
}

\author{
Sapto Dwi Anggoro
}

Sekolah Tinggi Ilmu Kesehatan Hang Tuah Surabaya, Indonesia

Correspondence: Sapto Dwi Anggoro, Sekolah Tinggi Ilmu Kesehatan Hang Tuah Surabaya, Indonesia. e-mail: saptoanggoro@yahoo.com

Submitted: January 29, 2020

DOI: $10.29408 /$ veles.v4i1.1894
Revised: March 04, $2020 \quad$ Accepted: March 07, 2020

URL: http://dx.doi.org/10.29408/veles.v4i1.1894

\begin{abstract}
The need of speaking skill is inevitable in some areas of majors. Nursing students are expected to have good command of English due to the available opportunities to work abroad. The existence of academic exchange program could be viewed as one of an alternative learning method that may fit the needs of learning experience for EFL students. This study was a qualitative research that aimed at finding communication problems encountered by Indonesian nursing students in their interactions with their counterparts during the academic exchange program held in a nursing college in Thailand. The participants of the study were six Indonesian nursing college students taking part in the academic exchange program in Thailand. The instruments of the study were audio transcripts and interviews. The data were collected through audio recording during the academic exchange in Thailand and the interviews were conducted as the students returned to their home country. The results of the study showed that the communication problems encountered by Indonesian nursing students due to Thai students speaking ability were in terms of: mispronunciations, incorrect word choices, and grammatical errors. Subsequently it was also found that Thai nursing students used several strategies to cope with their speaking problems by for assistance, miming, and making repetition.
\end{abstract}

Keywords: Thai Nursing Students, Indonesian Nursing Students, Speaking ability, academic exchange.

\section{Introduction}

Practicing spoken English requires for EFL requires a great deal of learning experience. Widiati and Cahyono (2006) asserted that speaking English takes several stages. At the production level, speaking covers a complex mechanism where a speaker has to think not only how he/she works on grammatical and semantic properties of the language but also understands how native speakers speak the language in the context of structured interpersonal exchange. Further Shumin (2002) introduced a model of speaking proficiency that includes four components of competence. 


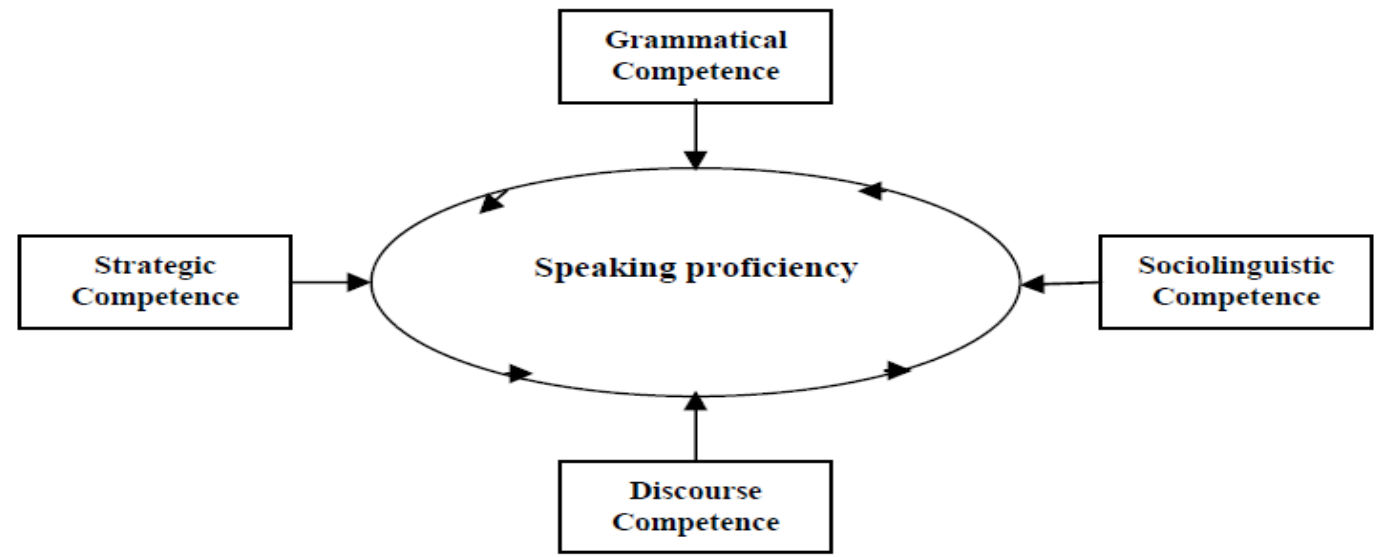

Figure 1. Speaking proficiency and the components of communicative competence (Shumin, 2002:207)

Following the above model, considerations on developing EFL speaking skill in Indonesian context should aim at those four components of speaking proficiency. The initial indicator of Indonesian students' speaking skill could be viewed from their vocabulary size. As reported by Nurweni and Read (1999), the first year of university students possessed approximately 1226 English words, which according to Nation (2006) was quite insufficient because the ideal measure should at least 3000 up to 5000 English words for that level. On achieving that level of vocabulary size, the students would be able to reach high proficiency standard in listening, reading, speaking and writing.

Due to the poor Indonesian students' vocabulary size, the EFL speaking practice is very much problematic. The use of English at an instruction level in the classroom is not very common and is seen as a failure, as stated by Renandya (2004). Learning experience of EFL in high schools that is not very satisfactory has been the main cause of the problems in EFL teaching and learning in higher education levels. Many freshman students are still struggling to work on their speaking ability. In the meantime the national curriculum of higher education insists on the development of students' centered learning where students are the center of the learning activities, reducing the traditional customs of classroom activities. This means that EFL students have to be very active in the classrooms doing varieties of activities to pursue new learning experience.

In order that EFL students get the most benefit of their learning processes, classroom activities should include a number of teaching components. Richards et al. (2013) suggests the following teaching aspects to be made available in EFL classes: 1) Making use of the target language resources; 2) Elaborating proper language models; 3) Encouraging feedbacks for language improvement; 4) Treating the target language as a medium of instruction in the classroom; 5) Providing appropriate description and accurate explication; 6) Introducing a wide range of language input; 7) Being able to improvise.

Speaking involves a mechanism in reception and production processes. Reception process is related to the ability the speaker to understanding messages. In addition speaking and writing is a part of process in language production. The latter is not discussed further in this study. In the meantime, the former is very much at the attention of EFL teachers. Speaking covers many areas of linguistics so that a speaker could produce meaningful and acceptable. 
In order to be competent a speaker should be able to apply related components that may influence their speaking skill. In line with this issue, Brown (2007) pointed out that speaking ability could be assessed through several components, in terms of: pronunciation, fluency, grammar, vocabulary, discourse feature, and task accomplishment. This is also confirmed by Saunders and O'Brien (2006) that appropriate forms of language use take a vital role in communication. Several linguistic factors consisting of pronunciation, grammar, and vocabulary should be taken into account.

In EFL settings one the most dominant factors for students is pronunciation. Pronunciation covers the areas of supra segmental and segmental. In supra segmental area the speaker elaborates their speech with stress, intonation, features of connected speech as well as voice quality. In segmental area, the speaker focuses on two skills, namely phonemes and gestures. Furthermore, Burns (2003) stated that students could communicate effectively if they have good basics of pronunciation and intonation. In oral performances, pronunciation and its related aspects could be seen as the most visible characteristics of speaking ability. Gilakjani (2012) asserted that poor pronunciation skill may decrease EFL students' selfconfidence that later affects their social interactions. Besides pronunciation, some factors also contribute to students' speaking ability.

Vocabulary or word choice could also characterize EFL students' speaking ability. At beginner levels, EFL students do not have the capability to talk or discuss about complicated topics in very academic or formal situations. In other words, EFL students who acquire very small numbers of words could only interact in very limited situations. Uzer (2017) confirmed this in his study on the correlation between the vocabulary mastery and speaking ability of tenth graders at Senior High School 12 in Palembang. Incorrect word choice is also taken as the domain of vocabulary mastery. The majority of EFL students are inhibited in speaking ability due to lacking of vocabulary. The last count of speaking ability is the assessment of grammatical accuracy.

Speaking skill is normally assessed for its fluency and accuracy. The latter is frequently associated with the use of grammar. It is often seen viewed as the rules for producing wellstructured language forms. Many arguments are made as to decide whether or not grammar should be taught in speaking classes. However, Harmer (2002) asserted that once the knowledge of grammatical rules is acquired, a speaker is supposedly able to produce an infinite number of utterances. In addition Baker and Westrup (2003) argued that grammar is accepted as a factor that inhibits EFL students' speaking ability. Though grammar might not be the central issue in speaking skill, the absence of grammatical knowledge may be the cause of students' inability to produce utterances. This could also be equally vital when grammatical errors may bring misunderstandings or communication break downs in oral interactions.

English Immersion Program has long been accepted as one of the most effective foreign language learning strategies. This program enables foreign language learners to interact directly with English native speakers. Learning experience is obtained through the interactions taking place during the program. This program provides a great variety of situations of the target language. Words, expressions, and other language properties are learned through real life experience. Every learning input is very much practical as well as functional since the characteristic of interaction is always spontaneous. All the above 
characteristics could contribute to the students' success in making their language active. This is confirmed by a study conducted by Ahmad Munir (2006). In his study he asserted that the students who study in Australia for one year could improve their English significantly. Their speaking competence improved not only in their fluency but also their sociolinguistic competence.

Having noticed all the above description on the benefits of academic exchange program, it is essential for language teachers to understand the whole aspects of foreign language learning found in that activity. In this regard, a private nursing school, Sekolah Tinggi Ilmu Kesehatan Hang Tuah Surabaya has been running academic exchange programs with Srimahasarakham Nursing College, a state nursing school from Thailand for almost eight years. This program is held every year, where six students and two lecturers are sent to the host school for two weeks. They all take participation in the host school for curricular activities, cultural understanding, and nursing education updates. The main interest of this program in view of EFL teaching and learning is the existence of interactions between two groups of EFL students. Hence, it is worth investigating to see all the aspects of communicative activity in their interactions and study the possibility of problems at the production level of the target language. This study focused on the speaking problems encountered by Indonesian Nursing Students in Their Interactions with Thai Nursing Students. This research was intended to answer the following questions:

1. What speaking problems take place in the interactions between Thai nursing students and their Indonesian counterparts during the Academic Exchange Program?

2. What strategies are used by Thai nursing students to cope with their speaking problems?

\subsection{Participants}

\section{Method}

The participants of this study were six students from a private nursing school in Surabaya, who were selected to be the participants of the academic exchange 2019. The selection stage was carried out on the basis of EFL mastery assessment. They were identified to have paper based TOEFL scores above 500. They were also members of Nursing English Community (NEC), which is an extracurricular activity intended for students who are motivated to learn English for health and caring purposes.

\subsection{Data Collection}

\subsubsection{Instrument of Collecting Data}

Research instruments applied in this study were in terms of audio records, interviews, and observation notes. Audio records were used to collect data from the interactions between Indonesian and Thai nursing students, in which the main data in terms of verbal communication were obtained. This covered some linguistic areas, such as pronunciation, word-choice, and grammar. Apart from that observation notes were used to assess non-verbal communication that may consist of linguistic behavior and body language as well as gesture that indicated how Thai nursing students responded during the interactions and the way they reacted to inquiries as well as the strategies they used to cope with situations, where they found communication problems. At the last stage interviews were used to clarify and confirm the data obtained through audio recordings and observation notes. 


\subsubsection{Techniques for Collecting Data}

Data collection procedure was carried out in several stages It was initiated by sending a letter to request for conducting research at STIKES Hang Tuah Surabaya. The data collection was not be started until the permit obtained from the head of STIKES Hang Tuah Surabaya. Briefing the participants was then carried out to make sure that the participants could record the conversations under the expected situations. Subsequently, informed consent was given to the participants as to confirm their participations in this research. The participants also asked their counterparts, Thai nursing students for consent prior to recording processes. The recording lasted for twelve days during the academic exchange 2019. At the end of the academic exchange the participants returned the audio recording devices and its files to the researcher.

\subsection{Data Analysis}

The data analysis was initially conducted through identifying data from the audio transcripts which were broken down into some categories. The conversations were accepted as the sources of the data by which the findings were formulated. The subsequent analysis was taken from the interviews in order to generate detailed information and was also accepted as the triangulation to confirm the data. The analyzed data were then used to formulate findings and answer the research questions.

\section{Findings}

\subsection{TNS Speaking Ability}

The nature of Thai-Indonesian nursing students' interactions is characterized by the use of gestures and other types of body language. In the first phase of contact between two groups of students communicating in English as their second language, excitement appears on every interaction among them. The first reason is because they want to display hospitality and warm welcome. At the same point both students gain the first experience of using their English in real communication setting, where English is the only accepted language to communicate and build interpersonal relationship. Two groups of students feel the more I speak, the more I know about my foreign fellow students. Each group has so much intensity of interaction though the response could be just smiles, nods, and shakes of the head and sometimes very short replies, such as "yes" or "no" are very common. This certainly provides very good environment for both groups of students to interact in English. Since they use English as a foreign language, problems may arise as they communicate in every interaction

One of the major problems for INS to interact with their Thai counterparts is mispronunciation. The most difficult sounds to be perceived by INS consist of /v/, /l/, /s/. For instance, the word van is pronounced /waeng/ which is hard for INS to refer to a certain English word. Moreover, the word male is pronounced /maeu/ and choice is pronounced as /choi/. The above mispronunciations are unpredictable and hard to understand. In other cases some mispronunciations are slightly acceptable and easy to understand. This is because the mispronounced word is a part of a phrase where the listener could provide a proper prediction for the missing word. For example, when TNS mispronounced "go around" as /go/ /aloud/. Not having broad experience of communicating with TNS may lead INS to misunderstand 
and get incorrect interpretations. Thus, it is important for INS to recognize such problems and provide strategies to avoid communication barriers that possibly take place in any situations in academic exchange between INS and TNS.

For some INS, the use of incorrect word choice also contributes to their inability of understanding the messages shared by TNS. In several interactions INS find some misused words. Though it may not happen continuously but it could possibly disrupt the flow of conversations. TNS occasionally use improper dictions, such as "many summer season" instead of "long summer season" when they need to express a time span. Another case is incorrect word of "Trim" instead of "Shrimp" when they talk about food ingredients. This may not be serious when INS could identify the mistakes by connecting the utterances with the possible contexts shared in the interactions. However, failure in perceiving the meaning of words due to the improper word choice tends to lead INS to unexpected misinterpretations. To anticipate and minimize the impacts of miscommunication, students attempt several strategies that could help INS understand.

Some communication problems also take place at the syntax level, where grammatical errors are often identified. Though grammar seems to be less important in speaking, the presence of incorrect grammar could trigger to some miscommunication. When TNS ask questions, they do not use proper formulation of interrogatives. Instead they produce utterances such as "You can eat spicy foods?". This message may create some extent of confusion to INS. This could be accepted as permission, saying that you are allowed to eat spicy foods. In other words, it could also be accepted as a question, asking whether or not he/she can tolerate eating spicy foods. The idea of getting the meaning across of this message is through intonations that still characterize the use of interrogatives. Such faulty utterances used by TNS in formulating questions are not too much bothering INS to constantly interact with them. However, in some critical situations, improper ways of asking could indeed bring some misunderstandings. Other forms of mistakes could also be perceived as communication problems, for example when TNS use incorrect passive voices and possessive pronouns.

\subsection{Strategies Used By TNS To Cope with Their Speaking Problems}

It is common that the first contact of two groups of nursing students who do communicate in English as a first language has brought a new experience to both groups of students. Hesitations, the use of body language and gestures characterize the students' communication in such circumstances. Both INS and TNS struggle to keep the flow of conversation in each interaction. Efforts are sometimes need to be made when the students starts to get difficulties to understand each other. In doing so, they use various strategies to express their ideas and speak what they intend to say. Tarone (1983) classified communication strategy in five bases, namely: avoidance, paraphrase, borrowing, appeal for assistance, and mime.

One of the first strategies that TNS use to solve miscommunications is by code switching. In some situations when TNS need to confirm words, expressions or utterances, they call for help to their friends by code switching. By switching to their first language, they feel secured and free to get information from his/her friends without being embarrassed of not knowing something. When they feel blocked, they see the presence of their friends as the immediate 
assistance to solve their communication problems. This strategy is very effective when TNS attempt to solve misunderstandings in working with word choice and grammatical errors. Some situations show how much TNS depend intensively on this strategy. Apart from that some other strategies are also effective to solve communication problems

Miming is another form of strategy used to help TNS in their interactions with INS. It is often realized that particular references or the presence of certain objects are hard to explain or describe. When something is unfamiliar, such as the name of local foods or specific objects, occasionally extensive English vocabulary is required to make detailed descriptions so that the listeners or in this case, INS could have some pictures of the expected objects. In case of complicated or urgent situations, the use of gadgets or digital translations could also be alternative ways to provide instant descriptions, for example when TNS describe Songkran festival in very vivid details. Even though some strategies could be used to confirm some unclear messages but a few of them might not be relevant as well as effective.

The most immediate and spontaneous replies provided by TNS when they confirm misunderstandings are in the forms of repetitions, most of which are used when TNS fail to explain words as they could not produce proper pronunciations of a few words. As a matter of fact, the use of repetitions is not effective to emerge the expected meanings. This strategy is usually followed by body language and gesture. The use of this combination of strategies works well for some cases. In some other cases, such mechanisms do not work effectively. However, there is a way of getting the meaning across when there is a dead lock. In one of the speech events, paraphrasing is proved to be very effective. At a particular moment when one of the TNS explains the word "smile" of which she could not utter it properly. When repetitions fail, as well as body language and gesture, the TNS suddenly changes the word to become "smiling" and it is accepted correctly. This way of improving mispronunciation seems to be straight forward and accurate and it needs to be accepted as an alternative way to solve a dead lock in mispronunciation cases. It is advised that both groups of students, INS and TNS provide prefixes and suffixes as they find mispronunciations.

\section{Discussion}

In the academic exchange intensive interactions between INS and TNS has brought many advantages for both groups of students, especially for the development of EFL speaking skill. This program brings about wide opportunities for every participant to find new experiences in using English as the only accepted language in all interactions. This means the participants need to speak English in all available situations and build interpersonal relationships to one another. As a part of the experience in making use English, INS could see either how they communicate successfully or fail to maintain some interactions. As a matter of fact, some misunderstandings and failure occur in some circumstances, most of which are due to poor speaking ability on the part of the TNS. Some findings are analyzed and discussed and it could be concluded that TNS speaking ability is mostly at beginner levels. This assessment is made based on three aspects of linguistic areas in terms of: pronunciation, word-choice, and grammar.

Poor speaking skill is characterized by numerous mispronunciations. TNS who are still at the beginner levels could not pronounce some English words properly. It is confirmed in a 
research conducted by Diep (2017). Pronunciation and Grammar have been taken as two of the most dominant factors affecting EFL college students' speaking skills. Some of the TNS are still influenced by their first language when they use their English to interact. This problem becomes very serious when misunderstandings occur and they need to find strategies to maintain their interactions. Since they do not have much experience in using English, they make use of repetitions and gestures to compensate with the circumstances.

Though it is often ignored in English conversation classes, Grammar is proved to be a dominant factor in speaking skill. Grammatical errors are seen as one of the most serious problems in TNS speaking ability. INS see this as drawbacks in their interactions with TNS. During several interactions misunderstandings occur due to the incorrect use of some grammatical features, such as passive voice and possessive pronouns. Some other grammatical errors also occur but they could still be accepted because the meanings conveyed in the messages are still perceived. In a study of grammatical errors in speaking, Sari (2018) also found that those areas of grammatical errors frequently take place in EFL college students.

Another indicator of EFL students' poor speaking skill is incorrect word choice. This is due to insufficient knowledge of words in the target language. Most of the EFL students experience this problem in oral communication. This also becomes evidence in the academic exchange where TNS are found to use quite numerous incorrect words to interact with INS. Incorrect word choice could be one of the main reasons for miscommunications. Some TNS use some words that do not fit with the meanings that they expect to say. Such mistakes are very misleading and lead to confusion. This could happen because TNS seem to rarely make use of English in real interactions. In line with this, Seffar (2015) also confirmed that vocabulary has been one of the prominent factors influencing EFL speaking ability. A great variety of words should be introduced to EFL students in order to help them improve their oral communication skill.

\section{Conclusions}

Along with all communication problems occurring between INS and TNS during the academic exchange program, there are strategies used to enhance students' ability to cope with their speaking problems. The most common forms of strategies applied as miscommunication occurs are repetitions and body language. At the first stage, repetitions are used and secondly, TNS involve body language and gesture. Later when the messages are not confirmed, TNS switch to their first language by asking for help from his/her fellow students. Code switching mostly works effectively during the clarification processes. Eventually, when every attempt does not meet with the expected results, paraphrasing is considered as a way to get the message clearer. In case of mispronunciations in stem words, TNS could add prefixes or suffixes in order that the sounds of the words varied and by any chance INS could recognize the words that TNS expect to say.

In spite of some linguistic barriers, the academic exchange provides some benefits. Firstly the academic exchange program is a good conditioning in EFL learning especially for higher education students. It provides wide opportunities for Indonesian students to communicate in English in real interactions. The contact between Indonesian and Thai 
students has created rich varieties of situations where English is accepted as the only language used during the program. Secondly, most students participating in this program are very motivated and excited to get involved very actively. When interacting, the students are curious to see whether or not their language works in real situations. In addition, they have sufficient time to see different varieties of accents and intonations that characterize English spoken by Thai people. All this experience is valuable for EFL students, especially INS to provide practical views of spoken English and its further advancement.

In order that the academic exchange gets the most benefits to INS, this research eventually suggests a number of recommendations: 1). the students participating in the program should avoid using their first language even though they communicate with their own friends in the group. 2). the students are advised to share as much information as possible to activate their speaking strategies. 3). the students are expected to have self-confidence in all interactions with TNS. 4). the students must avoid unnecessary jokes, mocking TNS due to different cultural values. 5). Subsequently, A number of activities prior to the academic exchange should also be conducted in terms of 1). Practice in formulating questions, 2.) Introduction to Thai culture, 3). Introduction to Thai spoken English.

\section{References}

Ardian, R. W., Hamied, F. A., \& Nurkamto, J. (2018). English Language Proficiency in Indonesia: Issues and Prospects. The Journal of Asia TEFL, 618 - 629.

Ary, D., Jacobs, L. C., Sorensen, C. K., \& Razavieh, A. (2010). Introduction to Research in Education Eighth Edition. Wadsworth: Cengage Learning.

Baker, J., \& Westrup, H. (2003). Essential Speaking Skills: A Handbook for English Language Teachers. London: Continuum.

Bargaric, V. (2007). Defining Communicative Competence. Metodika, 8, 94 - 103.

Bergmann, J., \& Sams, A. (2012). Flip your classroom: Reach every student in every class every day. United States of America: ISTE.

Brown, H. D. (2007). Teaching By Principles: An Interactive Approach To Language Pedagogy. New York: Pearson Education Inc.

Burns, A. (2003). Clearly Speaking: Pronunciation in Action for Teachers. Sydney: AMEP Research Center.

Canale, M., \& Swain, M. (2002). Theoretical Bases of Communicative Approaches to Second Langauge Teaching and Testing. Applied Linguistics, I(1), 1 - 47.

Creswell, J. W. (2014). Research Design: Qualitative, Quantitative, and Mix Methods Approaches. Thousand Oaks, California: SAGE Publications, Inc.

Diep, L. T. (2017). Measurement of Factors Affecting English Speaking Skills of Students at The Foreign Languages Department of Van Lang University. Research And Science Today, Spring(1), 138 - 147.

Gilakjani, A. P. (2012). A Study of Factors Affecting EFL Learners' English Pronunciation Learning and The Strategies for Instruction. International Journal of Humanities and Social Science, 2(3), 119 - 128.

Gilakjani, A. P. (2016). English Pronunciation Instruction. International Journal of Research in English Education, 1(1), 1 - 6.

Harmer, J. (1991). The Practice of English Language Teaching. Essex, UK: Longman.

Harmer, J. (2002). The Practice of English Language Teaching. Cambridge: Pearson.

Kachru, Y., \& Nelson, C. (2006). World Englishes in Asian Context. Hongkong: Hongkong University Press. 
Lankshear, C., \& Knobel, M. (2008). Digital Literacies: Concepts, Policies, and Practices (New Literacies and Digital Epistemologies. New York: Peter Lang Publishing.

Mehring, J., \& Leis, A. (2018). Innovations in Flipping the Language Classroom. Singapore: Springer.

Munir, A. (2006). Studying in Australia to Improve English Speaking Competence: Revisitied. TEFLIN Journal, 89 - 106.

Musyahda, L. (2005). Strategic Competence: Bridging The Cross Cultural Communication. Teflin Journal, 71 - 78.

Nurweni, A., \& Read, J. (1999). The English Vocabulary Knowledge of Indonesian University Students. English for Specific Purposes, 18(2), 161 - 175.

Renandya, W. A. (2004). The Impact in East Asian Countries in the Next Decade. In H. W. Kam, \& R. Y. Wong, Language Policies and Language Education (pp. 115 - 131). Singapore: Eastern Universities Press.

Richards, H. M., Conway, C., Roskvist, A., \& Harley, S. (2013). Foreign Language Teachers' Language Proficiency And Their Language Teaching Practice. The Language Learning Journal, 41(2), 231 - 246.

Rini, J. E. (2014). English in Indonesia: Its Position Among Other Languages in Indonesia. Beyond Words, 19 - 39.

Roehl, A., Reddy, S. L., \& Shannon, G. J. (2013). Roehl, A., Reddy, S. L., \& Shannon, G. J. (2013). The flipped classroom: An opportunity to engage millennial students through active learning strategies. Journal of Family \& Consumer Sciences, 105(2), 44-49.

Sari, R. A. (2018). Students' Grammatical Error Analysis in Speaking. Jurnal Pendidikan dan Pengajaran, 5(2), 127 - 137.

Saunders, W., \& O'Brien, G. (2006). Oral Language. In F. Genesee, K. Lindholm-Leary, W. Saunders, \& D. Christian, Educating English Language Learners: A Synthetis of Research Evidence (pp. 14 - 45). Cmabridge: Cambridge University Press.

Seffar, S. (2015). The Effect of Vocabulary Knowledge on EFL Oral Competence. IOSR Journal of Research \& Method in Education, 5(6), 8-13.

Shumin, K. (2002). Factors to Consider: Developing Adult EFL Students Speaking Ability. (J. C. Richards, \& W. A. Renandya, Eds.) Methodology in Language Teaching, 204 211.

Staker, H., \& Horn, M. B. (2012). Classifying K-12 blended learning. San Mateo: Innosight Institute.

Tarone, E. (1983). Teaching Strategic Competence in the Foreign Language Classrooms. Studies in Language Learning, 121 - 130.

Tatsukawa, K. (2007). Developing An Assessment Tool for The Strategic Competence of Japanese EFL Learners. The Journal of Asia TEFL, 4(3), 71 - 92.

Tjokrokanoko, A., \& Tedjasuksmana, H. (2013). Students' Perceptions on NESTS and NNESTS. Beyond Words, 138 - 170.

Uzer, Y. V. (2017). The correlation Between Vocabulary Mastery and English Speaking Ability of the Tenth Grade Students of Senior High School 12 Palembang. AngloSaxon, 8(2), 251 - 258.

Widiati, U., \& Cahyono, B. B. (2006). The Teaching of EFL Speaking in The Indonesian Context: The State of Art. Jurnal Ilmu Pendidikan, 270 - 292. 